\title{
Book Review: Steven Spielberg: A Life in Films by Molly Haskell
}

New Haven and London: Yale University Press, 2017, 224 Pages, Rs. 1296, ISBN: 978-0-300-18693-2

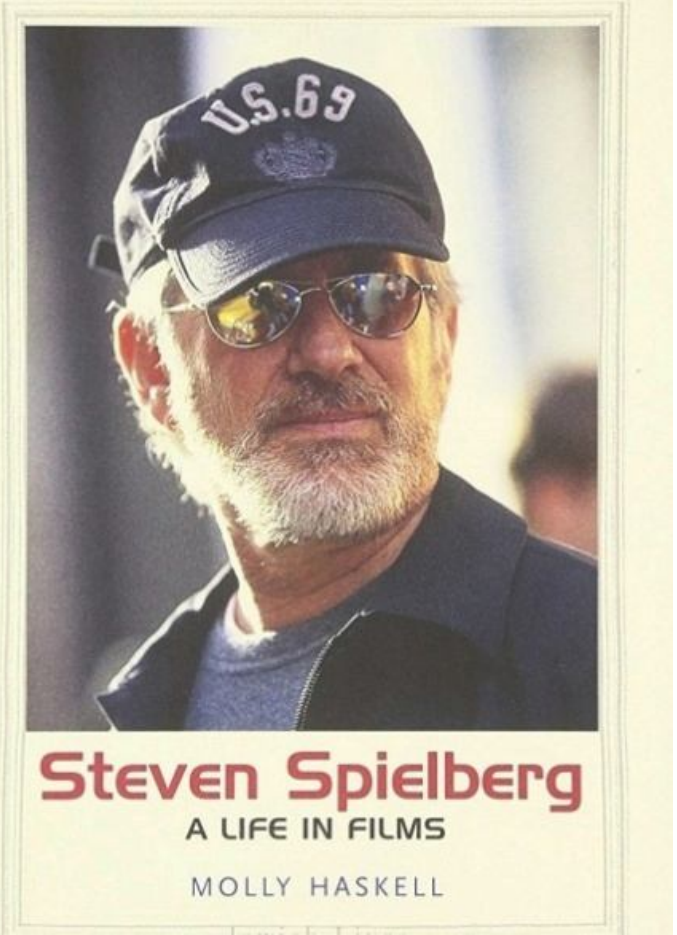

Reviewed by

\section{Shipra Gupta}

Research scholar, Kalinga Institute of Industrial Technology Deemed to be University, in the School of Humanities and Social Sciences ORCID: oooo-0oo1-8413-672X.

Email:luzaooog@gmail.com

In her book, Steven Spielberg: A Life in Films, Molly Haskell analyses 29 major films from the famed director's career by taking two to three films per chapter. She begins with the early years of Spielberg's life throwing light on the family's move to Arizona, his personal life with the absence of his father, his career in films and his staggering success later on. The book moves swiftly, blending the professional and personal aspects of his life together thus giving it a unified theme. The chapters are divided according to his films or groups of films as per their performance at the box-office, for instance, his failed movie 1941 is collaborated with the grand Raiders of the Lost Ark

(C) AesthetixMS 2018. This Open Access article is published under a Creative Commons Attribution Non-Commercial 4.0 International License (http://creativecommons.org/licenses/by-nc/4.0/), which permits non-commercial re-use, distribution, and reproduction in any medium, provided the original work is properly cited. For citation use the DOI. For commercial re-use, please contact editor@rupkatha.com. 
which make for illuminating contrasts. Haskell analyses each and every film through a religious, historical, cultural and political angle and also throws light on certain recurring motifs in the director's work, like the 'screaming woman', in most of his films.

In the process of working on the book, Haskell admits that she began to appreciate the artist's works and consider them worthy of the commercial success they earned. She observes that Spielberg changed the perception of blockbuster films and remained aloof to the critics' opinions; neither did he let their judgments affect the success of his films. Spielberg has critic-proofed himself, and that has provided him with an unrestricted career in Hollywood. She goes on to suggest that he always had a talent for multi-tasking. One would find him working on serious films alongside comic ones, action alongside period history, thriller as well as a romantic film simultaneously. Films like Schindler's List, Saving Private Ryan, The Color Purple, Amistad and Lincoln are some bright examples of his contrasting genres of works.

Molly Haskell has explored the varied genres of movies from Spielberg's career that highlight the director's creativity and the range of work he is capable of. His works oscillate between diligent prestige dramas to films which serve as enjoyable popcorn entertainment. Haskell has even mentioned interesting anecdotes from the film maker's life that would astonish as well as leave the readers awed, for instance, in the year 1993 Spielberg was working on Jurassic Park as well as Schindler's List simultaneously with equal amount of commitment and pleasure. It is surprising that films that are poles apart in their content and genre could excite and provoke him to work on them concurrently. She has taken into consideration blockbuster hits like - E.T, Close Encounters of the Third Kind, Indiana Jones and Jurassic Park as well as his lesser known but equally masterpieces like - A.I, Schindler's List and The Empire of the Sun.

As Haskell's narrative moves swiftly one learns that it was none other than Spielberg's father who got him acquainted with cameras and motivated him to make films, because of which we find dedications to him in many of Spielberg's movies. Yet, she couldn't fail to notice the oedipal conflicts reflected in his films owing to the absence of his father later in his life. She suggests that his films rarely portray sexually explicit scenes, rather, concentrate more on men who are somewhat afraid of women.

Haskell, in her book conveys to the readers that the film maker's personal life, his powerful storytelling capacity and his unique style of making films are all interwoven with his work and the times he lives in, e.g. his struggle against embracing Judaism and his relief thereafter, acted as the subtle driving force behind making Schindler's List. The opening of Haskell's book is completely biographical and the most informative; it outlines the complex that Spielberg faced of being a misfit nerdy Jew in Arizona, trying to cope up with his impulsive wish as a story teller who is torn between exploring the unknown yet missing his home while trying to fit in. This emotion of longing to escape as well as to belong has been reflected in some of the greatest movies by Spielberg, especially the ones based on science fiction like E.T, Close Encounters of the Third Kind and AI. For Haskell, Spielberg's finest film is J.G Ballard's adaptation, Empire of the Sun, a passionate film to which she devotes an elaborate chapter. We are also provided with Haskell's critical analysis about the film A.I, correcting the assumptions that the public held as to which parts of the film are Spielberg's, Stanley Kubrick's or both of them together. She has glorified the gripping yet flawed and misinterpreted movie. She also astonishes the reader with her insightful and appreciating take on Spielberg's The Color Purple, which was an adaptation of the novel by Alice Walker by the same name, by supporting the dynamics of lesbian relationship portrayed in the film. 
This unexpected alliance of subject and biographer, further emphasized by Haskell who being a non-Jewish is writing a book to be entered in Yale's Jewish Lives series, gives her work the apprehension and excitement found in the genre of romantic comedy to which Spielberg was most averse. One finds a crisp, playful affection in her criticism as she writes about the non-sexual content in his work, but she also confesses about a certain admiration and approval of his films for the politics found in their content about personal identity and belongingness. His impulsive 1989 film Always, has been critiqued sardonically, albeit in a defensive and protective manner, where she has finally proved her point of Spielberg's deep understanding of yearning and heartache even though desire and romance are not his forte. One can notice Haskell's work getting increasingly compressed as it moves from the 'typical' Spielbergian films like - Jaws, Duel, Close Encounters, E.T, Sugarland Express, Raiders of the Lost Ark and his first Oscar winning Schindler's List - to films made later in his mid-career like Saving Private Ryan, Jurassic Park, towards films much different from his customary genres like Catch Me If You Can, Bridge ofSpies, Munich and Lincoln.

To conclude, the brilliant passages make up for an interesting volume about the life and times, and the culture and films of an artist whose evasion of interviews has made it difficult to carry out substantial studies on him. However, Haskell's zest and humour throughout the chapters keep the readers engrossed, wishing the book could have gone on. It is a compliment to any work when the reader does not want it to end, and this rarity we find in our experience of Spielberg's world through the pen of Molly Haskell as jotted down in this exceptionally entertaining book.

\section{References:}

Breznican, A. (2015, June 20). 'Jaws' Anniversary: Steven Spielberg on how it was almost a different movie. Retrieved February 20, 2018, from http://ew.com/article/2015/06/20/jaws-40-steven-spielberg/

Freedland, J. (2018, February 23). Why The Post should win the 2018 best picture Oscar. Retrieved February 24, 2018, from https://www.theguardian.com/film/filmblog/2018/feb/23/why-the-post-should-win-2018best-picture-oscar-steven-spielberg-tom-hanks-meryl-streep

Haskell, M. (2017). Steven Spielberg: A Life in Films. Yale University Press.

Jr, M. F. (2012, December 06). Mike Fleming's Q\&A With Steven Spielberg: Why It Took 12 Years To Find 'Lincoln'. Retrieved February 19, 2018, from http://deadline.com/2012/12/steven-spielberg-lincolnmaking-of-interview-exclusive-383861/

Steven Spielberg. (n.d.). Retrieved February 20, 2018, from https://books.google.com/books/about/Steven_Spielberg.html?id=5E8oTv7F3zIC

Ms. Shipra Gupta is a research scholar at Kalinga Institute of Industrial Technology Deemed to be University, in the School of Humanities and Social Sciences. She has completed her Masters and M.Phil. in English from Utkal University with specialization in American Literature and Film Studies respectively. She has worked as a guest faculty for M.A in English Programme in DDCE, Utkal University. Her interests include Media Studies, Culture Studies, World Literature and Transcultural Adaptations. She has presented papers on film studies in national and international conferences and has published papers on the same. She is also involved in environmental causes and the welfare of stray animals, and is actively working towards her goals. 